
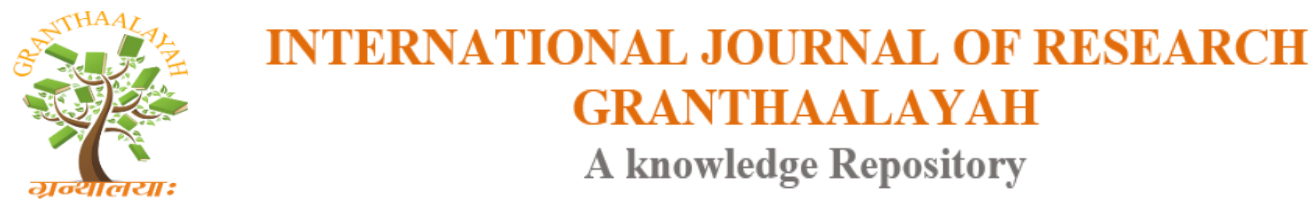

Management

\title{
AGRICULTURE: PROBLEMS AND SUGGESTIONS OF SATHANKULAM TALUK - TUTICORIN DISTRICT
}

\author{
Dr. M. Esakkiammal *1 \\ ${ }^{*}$ Assistant Professor of Economics Sadakathullah Appa College Tirunelveli, Tamilnadu, India.
}

\begin{abstract}
Agriculture is one of the most important pillars of the Indian economy. The contribution of agriculture and its allied sectors to India's GDP stood at 13.9\% during 2013-14. More than half of the Indian population is dependent on agriculture for its subsistence. Since the beginning years of economic development, it has been one of the main drivers of growth of the economy as it supplies was a major source of raw materials to most of the manufacturers. This paper focuses on exploring the socio-economic status of farmer in Tuticorin District, to draw findings, suggestion and conclusion.
\end{abstract}

Keywords: Agriculture; Problems and Suggestions; Tuticorin District.

Cite This Article: Dr. M.Esakkiammal. (2018). "AGRICULTURE: PROBLEMS AND SUGGESTIONS OF SATHANKULAM TALUK - TUTICORIN DISTRICT." International Journal of Research - Granthaalayah, 6(6), 75-80.

\section{Introduction}

Agriculture is the very backbone of the economic system and is her premier national industry. About 70 percent of the population is dependent on it for their livelihood. If we add the number of people indirectly depending on agriculture, the proportion will rise to more than three-fourths. It supplies the people with food as well as raw materials for their industries. Agriculture are a study, self-reliant class of people who are the backbone of the state. With their fixed outlook and attitude, they exercise a great stabilizing influence in the social and political sphere.

But at the same time, the predominance of agriculture in Indian economy is also a serious drawback. With the increasing number of people engaged in agriculture, pressure of population on cultivated land resources, recurring droughts, irregular monsoons and insect plagues, have kept agricultural production low. This is one of the fundamental causes of Indian poverty and her economic instability.

Agriculture is mainly operated by agricultural labourers. So, the role of the agricultural labourers is pivotal in agricultural production. The agricultural labourers are not skilled as industrial workers, yet they are the backbone of agricultural and Indian economy. ${ }^{1}$ 


\section{Literature Review}

Jens Larches analyzed the differences in agricultural scenario of east and west Uttar Pradesh in terms of 'semi-feudal stagnation and capitalist agrarian development', respectively, equating the former with the prevalence of strong oppressive structures. Rather, the post-independence land reforms have resulted in a split in the landowning class between the erstwhile thakur landlords and upcoming OBC peasantry, in east UP, thus providing space for the dalits to assert themselves in alliance with the OBCs, On the other hand, the capitalist development in west UP has maintained the monopoly of numerically stronger jets on landownership, thus negating any changes in rural social relations.

Mohanakumar explained that most of the relief packages to tackle the farm crisis do not cover agricultural labourers, who largely belong to scheduled castes and scheduled tribes. This article analyses the situation of agricultural laborers in the crisis-affected districts of Kerala - Wayanad, Idukki and Palakkad. It also reviews the performance of the welfare schemes for agricultural laborers which are implemented through the Agricultural Workers Welfare Fund Board.

\subsection{Objective of the Present Study}

1) To study socio-economic condition of the farmers in the Thoothukudi district

2) To draw findings, suggestion and conclusion.

\subsection{Sources of Study}

The data required for the study have been collected from both the primary and secondary sources. The primary data have been collected directly from Farmers by using Interview schedule. The secondary data have been collected from the published journal, books, magazines and websites.

\subsection{Analysis and Interpretation}

Analysis and interpretation are central steps in the research process. The aim of the analysis is to organize, classify and summarize the collected data so that they can be comprehended and interpreted to give answers to the questions that triggered the research. Interpretation is the search for the broader meaning of findings. Analysis is not fulfilled without interpretation; and interpretation cannot proceed without analysis. So, both are interdependent.

Table 1: Age Wise Classification

\begin{tabular}{|l|l|l|l|}
\hline S. No. & Age & No. of Respondents & Percentage \\
\hline 1. & Below 30 & 8 & 16 \\
\hline 2. & $30-40$ & 15 & 30 \\
\hline 3. & $40-50$ & 17 & 34 \\
\hline 4. & Above 50 & 10 & 20 \\
\hline & Total & 50 & 100 \\
\hline
\end{tabular}

Source: Primary Data 
Table: 1 reveals that 16 per cent of the respondents are under the age group below 30 per cent of the respondents are under the age group of 30-40. 34 per cent of the respondents are under the age group of 40-50 and 20 per cent respondents belong to the age group of above 50 .

Table 2: Sex Wise Classification

\begin{tabular}{|l|l|l|l|}
\hline S. No. & Sex & No. of Respondents & Percentage \\
\hline 1. & Male & 35 & 70 \\
\hline 2. & Female & 15 & 30 \\
\hline & Total & 50 & 100 \\
\hline
\end{tabular}

Source: Primary Data

Table: 2 shows that the sex level of the respondents in the study area. 70 per cent of the respondents are male and the remaining 30 per cent respondents are female.

Table 3: Educational Status

Source: Primary Data

\begin{tabular}{|l|l|l|l|}
\hline S. No. & Education & No. of Respondents & Percentage \\
\hline 1. & Illiterates & 5 & 10 \\
\hline 2. & Primary & 20 & 40 \\
\hline 3. & Middle & 15 & 30 \\
\hline 4. & Higher Secondary & 10 & 20 \\
\hline & Total & 50 & 100 \\
\hline
\end{tabular}

Among the 50 respondents, majority of the respondents have completed primary education.

Table 4: Nature of Family

Source: Primary Data

\begin{tabular}{|l|l|l|l|}
\hline S. No. & Nature of Family & No. of respondents & Percentage \\
\hline 1. & Joint family & 30 & 60 \\
\hline 2. & Nuclear family & 20 & 40 \\
\hline & Total & $\mathbf{5 0}$ & $\mathbf{1 0 0}$ \\
\hline
\end{tabular}

The family system of the respondents presented in table- 4 In the study area, 60 per cent of the respondents are belonging to the system of joint family. Only 40 per cent of the respondents are belonging to the nuclear family system.

Table 5: Size of the Family

\begin{tabular}{|l|l|l|l|}
\hline S. No & Family Members & No. of Respondents & Percentage \\
\hline 1. & Below 4 & 6 & 12 \\
\hline 2. & $4-5$ & 19 & 38 \\
\hline 3. & Above 5 & 25 & 50 \\
\hline & Total & $\mathbf{5 0}$ & $\mathbf{1 0 0}$ \\
\hline
\end{tabular}

Source: Primary Data 
The above table shows that 25 per cent of the farmers are having above 5 members in their family while 19 per cent of the respondents are having 4-5 members in their family and 6 per cent of the respondents are having below 3 members in their family.

Table 6: Level of Income (Per Year)

\section{Source: Primary Data}

\begin{tabular}{|l|l|l|l|}
\hline S. No. & Income (in Rs.) & No. of Respondents & Percentage \\
\hline 1. & Below 50,000 & 2 & 4 \\
\hline 2. & $50,000-1,00,000$ & 17 & 34 \\
\hline 3. & $1,00,000-1,50,000$ & 13 & 26 \\
\hline 4. & $1,50,000-2,00,000$ & 12 & 24 \\
\hline 5. & Above $2,00,000$ & 6 & 12 \\
\hline & Total & $\mathbf{5 0}$ & $\mathbf{1 0 0}$ \\
\hline
\end{tabular}

The above table- 6 explains that 4 per cent of the respondents are having income below Rs.50, 000 . 34 per cent of the respondent are having income between Rs.50,000 - Rs.1,00,000, 26 per cent of the respondent are having income between Rs.1,00,000-Rs.1,50,000, 24 per cent of the respondents are having income between Rs.1,50,000-Rs.2, 00,000. As well as the remaining 12 per cent of the respondents are having the income value above Rs.2, 00,000 per year.

Table 7: Indebtedness

Source: Primary Data

\begin{tabular}{|l|l|l|l|}
\hline S. No. & Particulars & No. of Respondents & Percentage \\
\hline 1. & Bank & 15 & 30 \\
\hline 2. & Chit funds & 7 & 14 \\
\hline 3. & Friends/Relatives & 8 & 16 \\
\hline 4. & Money lenders & 9 & 18 \\
\hline 5. & SHG & 11 & 22 \\
\hline & Total & $\mathbf{5 0}$ & $\mathbf{1 0 0}$ \\
\hline
\end{tabular}

From this table-7 it is clearly understood that the majority (30 per cent) of the respondents are getting loan from bank due to low interest rate.

Table 8: Problems

\begin{tabular}{|l|l|}
\hline Problems & Options \\
\hline Insufficient irrigation facilities: & $\mathrm{X} 1$ \\
\hline Problems of pests and diseases of crops: & $\mathrm{X} 2$ \\
\hline Lack of credit facility: & $\mathrm{X} 3$ \\
\hline Improper marketing & $\mathrm{X} 4$ \\
\hline Defective land tenure system & $\mathrm{X} 5$ \\
\hline
\end{tabular}

Source: Primary Data 
Calculation of weighted average method

\begin{tabular}{|c|c|c|c|c|c|c|c|c|c|c|c|}
\hline & & X1 & & $\mathrm{X} 2$ & & X3 & & X4 & & X5 & \\
\hline Rank & $\begin{array}{l}\text { Weight } \\
\text { (W) }\end{array}$ & $\mathrm{X} 1$ & X1 W & $\mathrm{X} 2$ & $\mathrm{X} 2 \mathrm{~W}$ & $\mathrm{X3}$ & X3 W & $\mathrm{X} 4$ & X4 W & $\mathrm{X5}$ & X5 W \\
\hline A & 5 & 18 & 90 & 12 & 60 & 11 & 55 & 6 & 30 & 13 & 65 \\
\hline $\mathrm{B}$ & 4 & 9 & 36 & 9 & 36 & 16 & 64 & 5 & 20 & 8 & 32 \\
\hline $\mathrm{C}$ & 3 & 8 & 24 & 15 & 45 & 8 & 24 & 13 & 39 & 12 & 36 \\
\hline $\mathrm{D}$ & 2 & 10 & 20 & 11 & 22 & 9 & 18 & 12 & 24 & 6 & 12 \\
\hline $\mathrm{E}$ & 1 & 5 & 5 & 3 & 3 & 6 & 6 & 14 & 14 & 11 & 11 \\
\hline TOTAL & & 50 & 175 & 50 & 166 & 50 & 167 & 50 & 127 & 50 & 156 \\
\hline Average & & \multicolumn{2}{|l|}{3.5} & \multicolumn{2}{|c|}{3.32} & \multicolumn{2}{|c|}{3.34} & \multicolumn{2}{|c|}{2.54} & \multicolumn{2}{|c|}{3.12} \\
\hline Rank & & \multicolumn{2}{|l|}{1} & $\frac{3.32}{2.2}$ & & 2 & 0.54 & 5 & & 4 & \\
\hline
\end{tabular}

\section{Findings}

- Study reveals that majority of the farmers are in their prime production age of 40-50 years (i.e) $37 \%$

- The analysis shows that majority of the farmers are male (i.e) 70 per cent.

- Majority of the farmers have completed only primary education (i.e) 40 per cent.

- In this study area, 60 per cent of the farmers are belonging to the system of Joint family.

- This study reveals that 50 per cent of the people are having above five members in their family.

- The income wise classification of farmers shows that 34 per cent of the farmers are having income between Rs.50000- Rs.100000.

- Majority of the farmers have borrowed money from Bank (i.e) 30 per cent.

- Majority of the farmers are affected by insufficient irrigation facilities.

\section{Suggestion}

\section{Adopting New Technologies}

We have failed badly in adopting new technologies.

\section{New Irrigation}

Methods have come like drip irrigation, sprinkling irrigation. These methods have proved success in water scant areas. For cultivation of vegetable, this types of irrigation can be a game changer.

\section{New Varieties}

New varieties have of paddy have come which requires lesser amount of water, but still produces same yield.

\section{Co-Operating Farming}

All the farmers in particular area should form an association. This association can act as medium or platform for an exchange of ideas, planning, water sharing and other things. These members if co-ordinate together many things can be done at a time, which will save a lot of money and resource. 


\section{Uzhavar Sandai}

The government should open one farmer's market in all urban cities, where farmers can sell their produce. Now these uzhavar Sandai are limited places and has not done any major contributions to farmers.

\section{Flexible Loans}

Government should come with dedicated funds to farmers. Where the interest rates should be minimal which farmer can bear in case of adversaries?

\section{Proper Maintenance of Water Resources}

All the water resources like dams, Lakes, Barrages and other things needs to be deslitted at regular intervals. This ensures maximum water storage.

\section{Conclusion}

To conclude that Agriculture is the most important occupation in the tuticorin district. Agriculture is basically the cultivation of plants for the production of food, fuel, fiber, medicines and many other things that have become a necessity for the mankind. Agriculture also involves the breeding animals. The development of agriculture turned to be a boon for the human civilization as it also gave way to their development.

\section{References}

[1] Jain S.C. (1963). "PROBLEM AND POLICIES OF INDIAN AGRICULTURAL". Kitab Mahal, Allahabad.

[2] S. Perumalsamy. "ECONOMIC DEVELOPMENT OF TAMILNADU" SPICES BOARD INDIA, Ministry of Commerce, Govt. of India.

[3] FOODGRAIN WASTAGE NEEDS TO BE PLUGGED: INDIAN MERCHANTS' CHAMBER PANEL DISCUSSION - The Times of India.

[4] Uppal J.S. (1983) “INDIA'S ECONOMIC PROBLEMS” Tata ME grew Hill Publishing Company Ltd, New Delhi.

*Corresponding author.

E-mail address: esakkiammal18@ gmail.com 